\title{
Fruit yield, growth and leaf-nutrient status of mango trees grafted on two rootstocks in a marginal growing area (South-East Spain)
}

\author{
Víctor Hugo Durán Zuazo ${ }^{a}$, Carmen Rocío Rodríguez Pleguezuelo ${ }^{a}$, Dionisio Franco TARIFA ${ }^{b}$
}

\begin{abstract}
a Centro de Investigación y Formación Agraria de Granada, IFAPA. Apdo. 2027, 18080 Granada, Spain duranzuazo@yahoo.com

b Finca Experimental "El Zahorí" Ayuntamiento de Almuñécar, Plaza de la Constitución 1, 18690 Almuñécar (Granada), Spain
\end{abstract}

${ }^{*}$ Correspondence and reprints

Received 23 February 2005 Accepted 18 November 2005

Fruits, 2006, vol. 61, p. 163-170 (C) 2006 Cirad/EDP Sciences All rights reserved DOI: 10.1051 /fruits:2006014 www.edpsciences.org

RESUMEN ESPAÑOL, p. 170
Fruit yield, growth and leaf-nutrient status of mangoes grafted on two rootstocks in a marginal growing area (South-East Spain).

Abstract - Introduction. Mango (Mangifera indica L.) production is rising in various subtropical zones throughout the world. The main polyembryonic rootstocks used by growers in South-East Spain are Gomera 1 and Gomera 3 (from the Canary Islands) and the most commonly used cultivars are Osteen and Keitt (from Florida, US). In this marginal environment for mango growing, it is important to determine the different rootstock qualities in order to optimise fruit production. The objective of our study was to evaluate the performance of mango cv. Osteen and Keitt on the two aforementioned rootstocks, as measured by fruit yield, scion growth and mineral nutrition. Materials and methods. A 3-year study was conducted in a mature mango orchard (14 years old) of a total of 24 trees, where eight were grafted onto cv. Osteen, another eight onto Keitt (four trees with each of the G1-Ost, G3-Ost, G1-Kt and G3-Kt combinations) and eight were ungrafted rootstocks. Fruit yield and pomological characteristics were evaluated by measuring fruit length, width and weight. Height and canopy diameter, as well as the trunk circumference of the tree, were recorded. Throughout the study period, chemical foliar measurements were taken from all trees. Results. Fruit yield in G1-Ost and G3-Kt trees proved significantly higher than that in the others. The fruit weight and length with the G3-Kt combination were greater than those with G1-Kt. Both cultivars grafted on Gomera 3 rootstock had the highest height and canopy volume. The tree-size data confirmed the vigorous feature of the Gomera 3. The $\mathrm{N}$ and $\mathrm{P}$ foliar concentration was significantly higher for Gomera 3 than for Gomera 1 in both cultivars. The K concentration was higher in G3-Kt leaves than in G1-Kt ones, but higher in G1-Ost than in G3-Ost. The leaf $\mathrm{Mn}$ and $\mathrm{Cu}$ concentrations with G3-Kt significantly exceeded those of G1-Kt. Conclusion. The height, trunk cross-sectional area, and canopy volume and diameter proved to be the greatest with Gomera 3, reflecting the vigour of this rootstock. The combinations G1-Ost and G3-Kt registered the highest fruit yield, offering promising possibilities for boosting subtropical productivity in mango.

Spain / Mangifera indica / variety trials / rootstocks / yields / plant nutrition

Rendement en fruits, croissance et nutrition foliaire de manguiers greffés sur deux porte-greffes dans une région de production marginale (sud-est de l'Espagne).

Résumé - Introduction. La production de mangues (Mangifera indica L.) s'accrôit dans diverses zones subtropicales du monde entier. Les principaux porte-greffes polyembryoniques employés par des agriculteurs au sud-est de l'Espagne sont Gomera 1 (G1) et Gomera 3 (G3) des îles Canaries et les cultivars le plus généralement exploités sont Osteen (Ost) et Keitt (Kt) de Floride, USA. Dans cet environnement marginal pour la croissance du manguier, il est important de caractériser les porte-greffes afin d'optimiser la production des fruits. L'objectif de notre étude a été d'évaluer la performance des cultivars de manguiers Osteen et Keitt sur les deux porte-greffes G1 et G3, en mesurant le rendement en fruits, la croissance du scion et la nutrition minérale. Matériel et méthodes. Une étude de 3 ans a été entreprise sur 24 arbres dans un verger de manguiers adultes âgés de 14 ans ; huit arbres ont été greffés sur Osteen et huit autres sur Keitt (quatre arbres pour chacune des combinaisons G1-Ost, G3-Ost, G1-Kt et G3-Kt) ; huit arbres porte-greffes n'ont pas été greffés ( 4 arbres G1 et 4 arbres G3). Le rendement en fruits et leurs caractéristiques pomologiques ont été évalués en mesurant la longueur, la largeur et le poids des fruits. La taille et le diamètre des frondaisons, ainsi que la circonférence du tronc de l'arbre ont été enregistrés. Tout au long de notre étude, des analyses de la composition chimique des feuilles ont été effectuées pour chacun des arbres. Résultats. Le rendement en fruits des arbres de G1-Ost et de G3-Kt s'est révélé significativement plus élevé que celui des autres combinaisons. Le poids et la longueur des fruits ont été plus importants avec la combinaison G3-Kt qu'avec les arbres G1-Kt. Les deux cultivars greffés sur le porte-greffe G3 ont eu la frondaison la plus importante. Les données portant sur la dimension des arbres ont confirmé la vigueur de Gomera 3. La concentration foliaire en N et P a été significativement plus élevée pour G3 que pour G1, quel que soit le cultivar greffé. La concentration en $\mathrm{K}$ a été plus forte dans des feuilles de G3-Kt que dans celles de G1-Kt, mais plus élevée pour G1-Ost que pour G3-Ost. La concentration des feuilles de G3-Kt en Mn et en $\mathrm{Cu}$ a été significativement plus élevée que celle de G1-Kt. Conclusion. La taille, la circonférence du tronc, et les volume et diamètre de frondaison ont été les plus importants avec G3, reflétant la vigueur de ce portegreffe. Les combinaisons G1-Ost et G3-Kt ont donné le rendement en fruits le plus élevé, offrant des possibilités prometteuses pour augmenter la productivité des manguiers en zone subtropicale.

Espagne / Mangifera indica / essai de variété / porte greffe / rendement / nutrition des plantes 


\section{Introduction}

Mango (Mangifera indica L.) cultivation is increasing in subtropical zones worldwide, and particularly in southern Spain (Granada and Malaga), where production is steadily rising due to the good yield potential in the area and to the expanding European markets with their demand for Spanish fruit [1, 2]. Studies in many tropical parts of the world have demonstrated the strong influence of mango polyembryonic rootstocks on the fruit yield, growth and mineral nutrition of the cultivar [3-6].

The main polyembryonic rootstocks used by growers, Gomera 1 and Gomera 3 (from the Canary Islands), are widely used in South-East Spain [7], and the scions most commonly used in the zone, for the excellent flavour as well as commercial value, include the Florida (US) cultivars Osteen, Keitt, Tommy Atkins, Irwin and Sensation [8, 9]. Studies on the effect of the rootstock on cultivar behaviour are meagre in mango adapted to subtropical conditions [10-12]. In these marginal environments for this crop, it is important to determine the different rootstock qualities in order to optimise the fruit production.

The main objective of our study was to evaluate the performance of the mango cvs. Osteen and Keitt on two rootstocks as measured by fruit yield, growth and mineral nutrition.

\section{Materials and methods}

The study, spanning three years (20002002) on the experimental farm "El Zahorí" in the area of Almuñécar, SE Spain, was conducted on orchard terraces on a south-facing slope cultivated with 14-year-old mango trees under a drip irrigation system. Twentyfour trees, planted $3 \mathrm{~m}$ apart, were studied, twelve with the rootstock Gomera 1 (G1) and twelve with Gomera 3 (G3).

Four G1 trees were grafted onto the cultivar Osteen (G1-Ost) and four other G1 trees were grafted onto the cultivar Keitt (G1-Kt). The same went for the G3 trees (G3-Ost and G3-Kt), while the remaining four trees of each rootstock were ungrafted (four G1 and four G3 ungrafted trees), hereafter "ungrafted trees". Thus, the experimental design was a randomised complete block with four replicates. The fertiliser application rate per tree was $240 \mathrm{~g} \mathrm{~N}, 71 \mathrm{~g}$ $\mathrm{P}_{2} \mathrm{O}_{5}$ and $212 \mathrm{~g} \mathrm{~K}_{2} \mathrm{O}$. The soil was typical Xerorthent [13], with a crumbly sandy texture (70\% sand, 25\% silt and 5\% clay), 0.92\% organic matter, $0.5 \% \mathrm{~N}, 44.0 \mathrm{mg} \mathrm{P} \cdot \mathrm{kg}^{-1}$ and $154.1 \mathrm{mg}$ exchangeable $\mathrm{K} \cdot \mathrm{kg}^{-1}$.

At the end of each harvest, fruit yields (kg fruits tree $^{-1}$ ) and pomological characteristics (length, width and weight of the fruits) were evaluated. Also, at this stage the height and canopy diameter as well as the trunk circumference of the tree $(15 \mathrm{~cm}$ above the bud union) were recorded. Canopy volume was calculated using the equation for one-half of a prolate spheroid [14, 15] and trunk circumference was converted into trunk cross-sectional area (TCSA) [16]. Throughout the study years, foliar measurements were taken from grafted and ungrafted trees from the middle part of the canopy, following the cardinal points and from normal shoots of similar physiological age. The $\mathrm{K}, \mathrm{Ca}, \mathrm{Mg}, \mathrm{Fe}, \mathrm{Zn}, \mathrm{Mn}$ and Cu concentrations in the plant material were determined by atomic-absorption spectrophotometry [17]. The $\mathrm{P}$ was determined by the molybdenum-blue method [18] and the total $\mathrm{N}$ by the Kjeldahl method [19].

An analysis of variance (ANOVA) was performed to determine the effect of the rootstocks on fruit yield, growth and foliar nutrient concentration. The measurements were evaluated by Duncan's multiple-range test at a level of 0.01 .

\section{Results and discussion}

Considering the fruit and tree characteristics for each combination tested over the 3-year study, significantly higher values appeared in G1-Ost and G3-Kt than in G3-Ost and in G1-Kt for fruit yield (table I). The normal alternate bearing of the mango was significant for both cultivars $(P<0.01)$. Also, the weight and length of fruits with G3-Kt were greater than those with the G1-Kt combination. Statistical differences appeared in fruit 
Table I.

Fruit and tree characteristics of cv. Osteen and Keitt on Gomera 1 and Gomera 3 rootstocks (Mangifera indica, Spain).

\begin{tabular}{|c|c|c|c|c|c|c|c|c|c|}
\hline \multirow{2}{*}{$\begin{array}{l}\text { Cultivar / } \\
\text { rootstock }\end{array}$} & \multicolumn{5}{|c|}{ Fruit characteristics } & \multicolumn{4}{|c|}{ Tree characteristics } \\
\hline & $\begin{array}{c}\text { Yield } \\
\left(\mathrm{kg}^{\left.- \text {tree }^{-1}\right)}\right.\end{array}$ & $\begin{array}{l}\text { Number of } \\
\text { fruits } \cdot \text { tree }^{-1}\end{array}$ & $\begin{array}{l}\text { Weight } \\
\text { (g) }\end{array}$ & $\begin{array}{l}\text { Length } \\
(\mathrm{cm})\end{array}$ & $\begin{array}{l}\text { Width } \\
(\mathrm{cm})\end{array}$ & $\begin{array}{l}\text { Trunk cross- } \\
\text { sectional area } \\
\left(\mathrm{cm}^{2}\right)\end{array}$ & $\begin{array}{l}\text { Canopy } \\
\text { diameter } \\
\text { (m) }\end{array}$ & $\begin{array}{l}\text { Height } \\
\text { (m) }\end{array}$ & $\begin{array}{l}\text { Canopy } \\
\text { volume } \\
\left(\mathrm{m}^{3}\right)\end{array}$ \\
\hline \multicolumn{10}{|l|}{ Osteen } \\
\hline Gomera 1 & $17.7 \mathrm{a}$ & $31 \mathrm{a}$ & $569.6 \mathrm{a}$ & $13.1 \mathrm{a}$ & $8.9 \mathrm{a}$ & $624.5 \mathrm{a}$ & $1.71 \mathrm{a}$ & $2.6 \mathrm{a}$ & $3.9 a$ \\
\hline Gomera 3 & $15.1 \mathrm{~b}$ & $26 \mathrm{~b}$ & $580.8 \mathrm{a}$ & $13.2 \mathrm{a}$ & $9.2 \mathrm{~b}$ & $670.4 \mathrm{a}$ & $1.74 \mathrm{a}$ & $3.0 \mathrm{~b}$ & $4.8 \mathrm{a}$ \\
\hline \multicolumn{10}{|l|}{ Year } \\
\hline 1st & $13.5 \mathrm{a}$ & $24 \mathrm{a}$ & $561.5 \mathrm{a}$ & $13.5 \mathrm{a}$ & $9.1 \mathrm{a}$ & $589.6 \mathrm{a}$ & $1.77 \mathrm{a}$ & $2.4 \mathrm{a}$ & $4.0 \mathrm{a}$ \\
\hline 2nd & $16.9 \mathrm{~b}$ & $31 \mathrm{~b}$ & $546.0 \mathrm{a}$ & $13.0 \mathrm{~b}$ & $8.9 \mathrm{a}$ & $670.8 \mathrm{a}$ & $1.75 \mathrm{a}$ & $2.7 a b$ & $4.3 \mathrm{a}$ \\
\hline 3rd & $15.9 \mathrm{~b}$ & $27 \mathrm{~b}$ & $590.0 \mathrm{~b}$ & $12.9 \mathrm{~b}$ & $8.9 \mathrm{a}$ & $700.1 \mathrm{a}$ & $1.80 \mathrm{a}$ & $2.8 \mathrm{~b}$ & $4.7 \mathrm{a}$ \\
\hline \multicolumn{10}{|l|}{ Keitt } \\
\hline Gomera 1 & $17.2 \mathrm{a}$ & $22 \mathrm{a}$ & $780.4 \mathrm{a}$ & $13.3 \mathrm{a}$ & $10.0 \mathrm{a}$ & $600.8 \mathrm{a}$ & $1.63 \mathrm{a}$ & $2.3 \mathrm{a}$ & $3.2 \mathrm{a}$ \\
\hline Gomera 3 & $20.8 \mathrm{~b}$ & $24 \mathrm{a}$ & $864.7 \mathrm{~b}$ & $13.8 \mathrm{~b}$ & $10.7 \mathrm{~b}$ & $675.3 \mathrm{a}$ & $1.71 \mathrm{a}$ & $3.2 b$ & $4.8 \mathrm{~b}$ \\
\hline \multicolumn{10}{|l|}{ Year } \\
\hline 1st & $19.9 \mathrm{a}$ & $25 \mathrm{a}$ & $798.2 \mathrm{a}$ & $13.2 \mathrm{a}$ & $10.2 \mathrm{a}$ & $623.5 \mathrm{a}$ & $1.69 \mathrm{a}$ & $2.3 \mathrm{a}$ & $3.4 \mathrm{a}$ \\
\hline 2nd & $17.2 \mathrm{~b}$ & $22 \mathrm{~b}$ & $784.5 \mathrm{a}$ & $13.0 \mathrm{a}$ & $10.0 \mathrm{a}$ & $648.5 \mathrm{a}$ & $1.74 \mathrm{a}$ & $2.4 \mathrm{a}$ & $3.8 \mathrm{a}$ \\
\hline 3rd & $21.1 \mathrm{a}$ & $25 a$ & $845.7 \mathrm{a}$ & $13.4 \mathrm{a}$ & $10.4 \mathrm{a}$ & $687.4 \mathrm{a}$ & $1.77 \mathrm{a}$ & $2.9 \mathrm{~b}$ & $4.8 \mathrm{~b}$ \\
\hline
\end{tabular}

For each cultivar, values with different letters in the columns are significantly different according to Duncan's test at $P<0.01$.

width with Gomera 1 for both cultivars, being smaller than with the Gomera 3. Both cultivars grafted onto the Gomera 3 rootstock had the highest height, and the canopy volume for G3-Kt significantly differed from that of trees with G1-Kt. In addition, the trends of TCSA and canopy diameter were greater with Gomera 3. In this sense, the Gomera 3 rootstock tended to be more vigorous than Gomera 1. Thus, given that Osteen has a medium-late harvest (October-November) and Keitt is late (November-December), the above combinations offer good yield for two different needs.

The values of tree size from ungrafted rootstocks corroborated the results for the grafted trees in relation to the vigorous feature of the Gomera 3. According to this information, the height and canopy volume of G3 trees were significantly greater than for those of G1 (table II). Also, the trend for ungrafted G3 trees in TCSA and canopy diameter was similar to the grafted ones with no statistical differences $(P<0.01)$.

\begin{tabular}{|c|c|c|c|c|}
\hline $\begin{array}{l}\text { Ungrafted } \\
\text { rootstock }\end{array}$ & $\begin{array}{l}\text { Trunk cross- } \\
\text { sectional area } \\
\left(\mathrm{cm}^{2}\right)\end{array}$ & $\begin{array}{l}\text { Canopy } \\
\text { diameter } \\
\text { (m) }\end{array}$ & $\begin{array}{l}\text { Tree } \\
\text { height } \\
\text { (m) }\end{array}$ & $\begin{array}{c}\text { Canopy } \\
\text { volume } \\
\left(\mathrm{m}^{3}\right)\end{array}$ \\
\hline Gomera 1 & $656.6 \mathrm{a}$ & $1.82 \mathrm{a}$ & $2.8 \mathrm{a}$ & $4.9 \mathrm{a}$ \\
\hline Gomera 3 & 745.7 a & $1.98 \mathrm{a}$ & $3.3 \mathrm{~b}$ & $6.7 \mathrm{~b}$ \\
\hline \multicolumn{5}{|l|}{ Year } \\
\hline 1st & $626.6 \mathrm{a}$ & $1.80 \mathrm{a}$ & $2.6 \mathrm{a}$ & $4.4 \mathrm{a}$ \\
\hline 2nd & 707.9 a & $1.88 \mathrm{a}$ & $3.0 \mathrm{ab}$ & $5.6 \mathrm{ab}$ \\
\hline $3 r d$ & $731.5 \mathrm{a}$ & $1.90 \mathrm{a}$ & $3.5 \mathrm{~b}$ & $6.6 \mathrm{~b}$ \\
\hline
\end{tabular}

Yield in the study zone differed appreciably from that of fully tropical climates, where both tree size and yield are greater. The climatic conditions in southern Spain represent the marginal limit for the mango 
Table III.

Macro- and micronutrient leaf concentrations of cv. Osteen and Keitt on Gomera 1 and Gomera 3 rootstocks (Mangifera indica, Spain).

\begin{tabular}{|c|c|c|c|c|c|c|c|c|c|}
\hline \multirow{2}{*}{$\begin{array}{l}\text { Cultivar / } \\
\text { rootstock }\end{array}$} & $\mathrm{N}$ & $P$ & $\mathrm{~K}$ & $\mathrm{Ca}$ & $\mathrm{Mg}$ & $\mathrm{Fe}$ & $\mathrm{Zn}$ & $\mathrm{Mn}$ & $\mathrm{Cu}$ \\
\hline & \multicolumn{5}{|c|}{ (\%) } & \multicolumn{4}{|c|}{$\left(\mathrm{mg} \cdot \mathrm{kg}^{-1}\right)$} \\
\hline \multicolumn{10}{|l|}{ Osteen } \\
\hline Gomera 1 & $1.77 \mathrm{a}$ & $0.11 \mathrm{a}$ & $0.45 a$ & $2.13 \mathrm{a}$ & $0.19 a$ & $95 \mathrm{a}$ & $19 a$ & $173 a$ & $23 a$ \\
\hline Gomera 3 & $1.89 \mathrm{~b}$ & $0.13 b$ & $0.50 \mathrm{~b}$ & $2.16 \mathrm{a}$ & $0.16 \mathrm{a}$ & $94 \mathrm{a}$ & $23 \mathrm{~b}$ & $175 a$ & $25 a$ \\
\hline \multicolumn{10}{|l|}{ Year } \\
\hline 1st & $1.75 \mathrm{a}$ & $0.13 a$ & $0.58 \mathrm{a}$ & $1.98 \mathrm{a}$ & $0.17 \mathrm{a}$ & 95 a & $18 a$ & $176 a$ & $25 a$ \\
\hline 2nd & $1.88 \mathrm{~b}$ & $0.13 a$ & $0.46 \mathrm{~b}$ & $2.15 \mathrm{a}$ & $0.20 \mathrm{a}$ & $98 \mathrm{a}$ & $24 \mathrm{~b}$ & $166 \mathrm{a}$ & $22 \mathrm{a}$ \\
\hline $3 r d$ & $1.85 b$ & $0.12 a$ & $0.48 \mathrm{~b}$ & $2.16 \mathrm{a}$ & $0.18 a$ & $100 \mathrm{a}$ & $22 b$ & $182 a$ & $23 a$ \\
\hline \multicolumn{10}{|l|}{ Keitt } \\
\hline Gomera 1 & $1.85 \mathrm{a}$ & $0.12 \mathrm{a}$ & $0.64 \mathrm{a}$ & $1.97 \mathrm{a}$ & $0.21 \mathrm{a}$ & $87 \mathrm{a}$ & $18 a$ & $181 \mathrm{a}$ & $19 a$ \\
\hline Gomera 3 & $2.07 \mathrm{~b}$ & $0.15 b$ & $0.51 \mathrm{~b}$ & $2.62 b$ & $0.21 \mathrm{a}$ & $102 b$ & $20 a$ & $249 b$ & $27 \mathrm{~b}$ \\
\hline \multicolumn{10}{|l|}{ Year } \\
\hline 1st & $1.88 \mathrm{a}$ & $0.10 a$ & $0.62 \mathrm{a}$ & $1.95 \mathrm{a}$ & $0.20 \mathrm{a}$ & $86 a$ & $20 a$ & $195 a$ & $22 \mathrm{a}$ \\
\hline 2nd & $1.94 \mathrm{ab}$ & $0.13 b$ & $0.56 \mathrm{~b}$ & $2.60 \mathrm{~b}$ & $0.22 \mathrm{a}$ & $105 \mathrm{~b}$ & $18 a$ & $230 \mathrm{~b}$ & $29 \mathrm{~b}$ \\
\hline $3 r d$ & $2.15 b$ & $0.14 \mathrm{~b}$ & $0.53 \mathrm{~b}$ & $2.55 \mathrm{a}$ & $0.21 \mathrm{a}$ & $84 \mathrm{a}$ & $19 a$ & $237 b$ & $30 \mathrm{~b}$ \\
\hline
\end{tabular}

For each cultivar, values with different letters in the columns are significantly different according to Duncan's test at $P<0.01$.

\section{Table IV.}

Macro- and micronutrient leaf concentrations in ungrafted trees of Gomera 1 and Gomera 3 rootstocks (Mangifera indica, Spain).

\begin{tabular}{cccccccccc}
\hline $\begin{array}{c}\text { Ungrafted } \\
\text { rootstock }\end{array}$ & $\mathrm{N}$ & $\mathrm{P}$ & $\mathrm{K}$ & $\mathrm{Ca}$ & $\mathrm{Mg}$ & $\mathrm{Fe}$ & $\mathrm{Zn}$ & $\mathrm{Mn}$ & $\mathrm{Cu}$ \\
\hline Gomera 1 & $1.40 \mathrm{a}$ & $0.07 \mathrm{a}$ & $0.41 \mathrm{a}$ & $1.79 \mathrm{a}$ & $0.23 \mathrm{a}$ & $90 \mathrm{a}$ & $15 \mathrm{a}$ & $238 \mathrm{a}$ & $14 \mathrm{a}$ \\
Gomera 3 & $1.55 \mathrm{~b}$ & $0.09 \mathrm{~b}$ & $0.45 \mathrm{~b}$ & $2.17 \mathrm{~b}$ & $0.25 \mathrm{a}$ & $96 \mathrm{a}$ & $19 \mathrm{~b}$ & $269 \mathrm{~b}$ & $20 \mathrm{~b}$ \\
\hline Year & & & & & & & & \\
1st & $1.42 \mathrm{a}$ & $0.07 \mathrm{a}$ & $0.42 \mathrm{a}$ & $1.89 \mathrm{a}$ & $0.21 \mathrm{a}$ & $100 \mathrm{a}$ & $16 \mathrm{a}$ & $222 \mathrm{a}$ & $15 \mathrm{a}$ \\
2nd & $1.51 \mathrm{ab}$ & $0.08 \mathrm{ab}$ & $0.47 \mathrm{~b}$ & $2.25 \mathrm{~b}$ & $0.24 \mathrm{a}$ & $97 \mathrm{a}$ & $21 \mathrm{~b}$ & $231 \mathrm{a}$ & $19 \mathrm{ab}$ \\
3rd & $1.57 \mathrm{~b}$ & $0.10 \mathrm{~b}$ & $0.48 \mathrm{~b}$ & $1.95 \mathrm{ab}$ & $0.23 \mathrm{a}$ & $95 \mathrm{a}$ & $20 \mathrm{~b}$ & $281 \mathrm{~b}$ & $22 \mathrm{~b}$ \\
\hline
\end{tabular}

Values with different letters in the columns are significantly different according to Duncan's test at $P<0.01$.

to develop normally, and, therefore, the dimensions of the tree and its yield are lower. However, this condition allows orchards to have a dense planting grid $\left(\approx 660\right.$ trees $\left.\cdot \mathrm{ha}^{-1}\right)$, facilitating harvest and pesticide applications, this high density cur- rently being a trend in intensive mango cultivation [20, 21].

The influence of rootstock on the fruit yield is a well-known fact. In Spain, Martínez et al. [22] and Durán et al. [12] reported 
greater yield of cv. Osteen with Gomera 1 even under saline conditions, while in Australia, Smith et al. [23] pointed out that cv. Tommy Atkins yielded 43\% more on Turpentine rootstock than on Sabre. Similar examples were reported in Venezuela [24] and in India [25]. According to our results, the effect of the rootstock on the fruit dimensions of the cultivar is great, especially with Gomera 3, in agreement with Avilan et al. [26] and Goncalves et al. [27], who indicated the notable influence of the rootstock-scion combinations on the dimensions of the fruit, weight and shape.

In our experiment, vigorous components of Gomera 3 were identified, being more notable in the ungrafted trees. Also, the values of all measured parameters in the trees tended to increase over time, height and canopy volume being significant. In this context, yield efficiency expressed as fruit yield per unit of canopy volume $\left(\mathrm{kg} \cdot \mathrm{m}^{-3}\right)$ correlated inversely with the vigour components and canopy size in Gomera 3, as noted in other studies on mango rootstock [28] and on rootstocks in other tree species [15, 29].

The analysis of variance for foliar nutrient concentration in grafted trees reveals that, in terms of nutrient-uptake efficiency, $\mathrm{N}$ and $\mathrm{P}$ concentration in both cultivars (Osteen and Keitt) was significantly lower in Gomera 1 than in Gomera 3 (table III). Meanwhile, for the $\mathrm{K}$ concentration, results in G3-Ost leaves were higher than those in G1-Ost ones, whereas concentrations in G1-Kt leaves were significantly higher than those in G3-Kt leaves. For both cultivars, the Mg leaf concentration was not affected by either rootstock. However, the Ca concentration in G3-Kt leaves was higher than that in G1-Kt. Over the study period, $\mathrm{N}$ and $\mathrm{K}$ concentrations with cv. Osteen increased, as did N, P, $\mathrm{Mn}$ and $\mathrm{Cu}$ concentrations with $\mathrm{cv}$. Keitt.

With regard to the micronutrients, the $\mathrm{Mn}$ and $\mathrm{Cu}$ concentrations in $\mathrm{G} 3$-Kt leaves were significantly higher than those in G1-Kt Also, the Zn concentration in G3-Ost leaves was higher than in G1-Ost.

Ungrafted trees registered significant differences in the foliar concentration of most of the nutrients, except for $\mathrm{Mg}$ and $\mathrm{Fe}$ (table IV). As in grafted trees, the highest concentrations for most of the nutrients were found for Gomera 3. In addition, for most of the nutrients, the foliar concentrations in the ungrafted trees were lower than those in the cultivars, with the exception of $\mathrm{Mg}$ and $\mathrm{Mn}$. During the three-year monitoring period, the foliar concentrations of $\mathrm{N}, \mathrm{P}$, $\mathrm{K}, \mathrm{Zn}, \mathrm{Mn}$ and $\mathrm{Cu}$ increased significantly in ungrafted trees.

The rootstock Gomera 3, having a root system with greater capacity for uptake and transport of macro- and micronutrients than Gomera 1, improved the mineral nutrition of the scion, as reflected directly in the foliar concentration of the cultivar. This agrees with Avilan [30], who contends that a rootstock with a vigorous root system provides the scion with effective mineral nutrition. Thus, in the case of good scion compatibility, it appears that the rootstock enables the grafted tree to achieve mineral nutrition comparable to that of an ungrafted tree of the same rootstock. If the rootstock belongs to a particularly vigorous species, the scion may reach optimal growth. Nevertheless, the rootstock-scion interaction is reciprocal, and the grafted portion can influence the size and composition of the root system, exerting an effect as strong as that of the roots on the shoot. According to Thomas and White [31], the mineral-uptake behaviour of an ungrafted rootstock is not necessarily the same as that of the rootstock grafted onto a scion. Our experiment with mango indicated that the effect of the rootstock on the uptake and foliar concentration of nutrients was similar in grafted and ungrafted trees. The rootstock, in providing the root system, not only must take up nutrients but must also confront negative factors in the soil and selectivity with respect to certain elements that may not coincide with the needs of the scion. In this regard, Durán et al. [12, 32] found the root system of Gomera 1 to be salt-tolerant, thus aiding the scion under saline conditions, while Gomera 3, for its higher ability to take up nutrients, proved to be more salt-sensitive.

The high leaf-nutrient concentration resulted in greater fruit yield of the G3-Kt combination than that of G1-Kt, reflecting the effectiveness of G3-Kt. In this sense, Reddy et al. [33] reported that high-yielding 
trees had higher leaf-N concentration than low-yielding trees. On the other hand, G1-Ost trees registered higher fruit-yield values than the G3-Ost combination despite the lower leaf-nutrient concentration, which is in agreement with Guzmán et al. [34], who found no relationship between the foliar nutrient concentration of $\mathrm{cv}$. Manila and fruit yield. The overall highest yield was registered by the G3-Kt combination, recommending it as a good general choice for high mango yield in marginal environments.

\section{Conclusion}

In general, the fruits obtained on Gomera 3 were significantly heavier and larger than those harvested on the Gomera 1 rootstock, especially for cv. Keitt. The height, trunk cross-sectional area, and canopy volume and diameter proved the greatest with Gomera 3, reflecting its vigour.

The rootstock Gomera 3 has a root system with a greater capacity of uptake and transport of macro- and micronutrients than that of Gomera 1, reflected in the foliar concentration and, therefore, the mineral nutrition of the scion. Thus, the rootstock, in the case of good scion compatibility, provides development and mineral nutrition comparable to those of the ungrafted tree of the same rootstock, as shown by the foliar concentrations in ungrafted trees in our study.

Our results demonstrate that fruit yield was greater for the Gomera 1-Osteen and Gomera 3-Keitt combinations, offering promising possibilities for boosting subtropical productivity in mango. In fact, Gomera 3-Keitt gave the highest yield of all combinations.

\section{Acknowledgements}

This research was partly sponsored by the Research Project "Environmental impact of the cultivation of subtropical species in steeply sloping lands. Integrated measures for the sustainable cultivation (RTA0500008-00-00)", granted by INIA, Spain.

\section{References}

[1] Anon., Statistical Database. Production and trade, FAOSTAT, 2005, http://apps.fao.org.

[2] Galán S.V., Mango world production (outside Israel, Egypt and India), Acta Hortic. 455 (1997) 15-22.

[3] Kurian M.R., Reddy P.V.V., Reddy Y.T.N., Growth, yield, fruit quality and leaf nutrient status of thirteen-year-old 'Alphonso' mango trees on eight rootstocks, J. Hortic. Sci. 71 (1996) 181-186.

[4] Nartvaranant P., Whiley W., Subhadrabandhu S., Pognart N., Suranant S., Effects of selected rootstock/scion combinations on $B$ uptake and plant growth of mango (Mangifera indica L.), Thai J. Agric. Sci. 2 (2003) 193205.

[5] Reddy Y.T.N., Kohli R.R., Singh E., Bhargava B.S., Effect of rootstocks on growth, yield and leaf nutrient composition of mango (Mangifera indica L.), Fruits 44 (1989) 409413.

[6] Singh U.R., Singh A.P., Rootstock studies in mango, Progress. Hortic. 8 (1976) 13-19.

[7] Galán S.V., García S.J., Pasado, presente y futuro del mango en Canarias, INIA, MAPA, Madrid, España, 1979.

[8] Galán S.V., Mango, in: Galán S.V. (Ed.), Los frutales tropicales en los subtrópicos, Mundi Prensa, Madrid, España, 1990, 54-94.

[9] Galán S.V., El cultivo del mango, Coed. Gob. Canarias CAGPA-Mundi Prensa, Madrid, España, 1999.

[10] Durán Z.V.H., Martinez R.A., Aguilar R.J., Effect of rootstocks on mineral nutrition of mango trees (Mangifera indica L. cv. Keitt), in: Villalobos F.J., Testi L. (Eds.), Proc. VII ESA Congr. Eur. Soc. Agron., Cordoba, Spain, 2002, 357-358.

[11] Durán Z.V.H., Martínez R.A., Aguilar R.J., Franco T.D., Impact of salinity on macro- and micronutrient uptake in mango (Mangifera indica L. CV. Osteen) with different rootstocks, Span. J. Agric. Res. 2 (2004) 121133.

[12] Durán Z.V.H., Martínez R.A., Aguilar R.J., Impact of salinity on the fruit yield of mango (Mangifera indica L. cv. Osteen), Eur. J. Agron. 21 (2004) 323-334.

[13] Anon., Soil survey staff. Soil taxonomy. A basic system of soil classification for making 
and interpreting soil surveys, USDA, Agric. Handb. 436, 2nd ed., Washington D.C., USA, 1999.

[14] Avilan R.L., Rodríguez M., Ruíz J., Marín C.R., Selección de patrones de bajo porte en mango, Agron. Trop. 47 (1997) 259-270.

[15] Castle W.S., Phillips R.L., Performance of Marsh grapefruit and Valencia orange trees on eighteen rootstocks in a closely spaced planting, J. Am. Soc. Hortic. Sci. 105 (1980) 496-499.

[16] Webster D.H., Brozono C.L., Trunk growth of apple trees as affected by fruit load, Can. J. Plant Sci. 60 (1980) 1385-1391.

[17] Chapman H.D., Pratt P.F., Method of analysis for soils, plants and waters, Univ. Calif. (Riverside), Div. Agric. Sci., Agr. Publ. Off., Univ. Hall Univ. Calif., Berkeley, USA, 1961.

[18] Fiske S., The colorimetric determination of phosphorus, J. Biol. Chem. 66 (1952) 375400.

[19] Bremner J.M., Total nitrogen, In: Black C.A., Evan D.D., White J.L., Clark F.E. (Eds.), Methods of analysis, Part 2, Agron. 9, Acad. Press, New York, 1965, 1149-1178.

[20] lyer C.P.A., Kurian R.M., Subhadrabandhu S., Tree size controls in mango (Mangifera indica L.), some considerations, Acta Hortic. 321 (1992) 425-436.

[21] Reddy N.N., Mathura R., Gangopadhyay K.K., Rai M., Prospects of high density orcharding in mango (Mangifera indica L.) in Eastern India, J. Res. Birsa-Agric. 14 (2002) 79-82.

[22] Martínez R.A, Durán Z.V.H., Aguilar R.J., Use of brackish irrigation water for subtropical farming production, in: Medina J.A., Zimmer D., Roest C.I.W., Yung-Hsu H., Bonn M. , Soon-Kuk K. (Eds.), Trans. 17th Congr. Irrig. Drain., Spec. Sess. ICID-CIID, Granada, Spain, 1999, 61-71.

[23] Smith M.W., Mark D., Hoult J.D., Bright S. McAlister S., Ford G., Rootstock research: opportunities for the Australian mango industry, Acta Hortic. 455 (1997) 383-390.
[24] Chauran O., Avilan R.L., Fruit index determination for some mango cultivars in the oriental zone of Venezuela, Agron. Trop. 31 (1981) 1-8.

[25] Reddy Y.T.N., Kurian R.J., Ramachander P.R., Singh G., Kohli R.R., Long-term effects of rootstocks on growth and fruit yielding patterns of 'Alphonso' mango (Mangifera indica L.), Sci. Hortic-Amsterdam 97 (2003) 95-108.

[26] Avilan R.L., Leal F., Rodriguez M., Ruiz J., Marin C.R., Mango rootstocks and their influence on fruit shape and size, Acta Hortic. 455 (1997) 479-488.

[27] Goncalves N.B., Carvalho V.D., Goncalves J.R., Coelho S.R.M., Silva T.G., Physical and chemical characterization of fruits of mango (Mangifera indica L.) cultivars, Ciênc. Agrotec. 22 (1998) 72-78.

[28] Kurian R.M., lyer C.P.A., Contribution and morphological growth components towards canopy development in mango, Gartenbauwissenschaft 62 (1997) 202-206.

[29] Rose M.L., Cole P.A., Atkin D., Kupper R.S., Yield and tree size of four citrus cultivars on 21 rootstocks in California, J. Am. Soc. Hortic. Sci. 144 (1989) 678-684.

[30] Avilan R.L., Sistema radicular del mango (Mangifera indica L.) en un regosol aluvial, Agron. Trop. 24 (1974) 3-10.

[31] Thomas F.B., White D.G., Foliar analyses of four varieties of peach rootstock grown at high and low potassium levels, Proc. Am. Soc. Hortic. Sci. 55 (1950) 56-59.

[32] Durán Z.V.H., Martínez R.A., Aguilar R.J., Salt tolerance of mango rootstock (Mangifera indica L. cv. Osteen), Span. J. Agric. Res. 1 (2003) 67-78.

[33] Reddy Y.T.N., Kurian R.M., Sujatha N.T., Srinivas M., Leaf and soil nutrient status of mango (Mangifera indica L.) grown in peninsular India and their relationship with yield, J. Appl. Hortic. 2 (2001) 78-81.

[34] Guzmán E.C., Mosqueda V.R., Alcalde B.S., Martínez G.A., Macro and micronutrient foliar content variation in mango cv. Manila, Acta Hortic. 455 (1997) 471-478. 


\section{Producción de frutos, crecimiento y estado nutricional foliar de mangos injertos en dos portainjertos en una región de producción marginal (Sureste de España).}

Resumen - Introducción. Las producciones de mango (Mangifera indica L.) están aumentando en diversas áreas subtropicales en todo el mundo. Los principales portainjertos poliembriónicos que usan los agricultores en el Sureste de España son Gomera 1 y Gomera 3 (procedentes de las Islas Canarias) y los cultivares más comúnmente utilizados son Osteen y Keitt (que proceden de Florida). En este ambiente marginal para el crecimiento del mango es importante determinar las cualidades de los distintos portainjertos para maximizar la producción de frutos. El objetivo de nuestro estudio fue evaluar el rendimiento de las variedades Osteen y Keitt en los dos mencionados portainjertos, midiendo la producción de fruta, el crecimiento del injerto y la nutrición mineral. Material y métodos. Se llevó a cabo un estudio de 3 años de duración en una parcela mangos adultos (de 14 años) con 24 árboles en total, ocho fueron injertados con el cv. Osteen, otros ocho con Keitt (los subgrupos de cuatro árboles fueron las siguientes combinaciones G1-Ost, G3-Ost, G1-Kt y G3-Kt) y otros ocho fueron portainjertos sin injerto alguno (francos). Se evaluó la producción y las características pomológicas de los frutos midiendo su longitud, anchura y peso. Se midieron el diámetro de la copa y la circunferencia del tronco de los árboles. A lo largo de todo el periodo de estudio se tomaron muestras para el análisis foliar. Resultados. Las producciones en los árboles G1-Ost y G3-Kt fueron mayores que en el resto. El peso y la longitud de los frutos con la combinación G3-Kt fueron mayores que con G1-Kt. Ambos cultivares injertados en Gomera 3 registraron los volúmenes de copa y altura del árbol más altos. Los resultados relacionados con el tamaño del árbol demostraron características vigorosas de Gomera 3. Los contenidos foliares de N y P fueron significativamente mayores en Gomera 3 que en Gomera 1 para ambos cultivares. La concentración de $\mathrm{K}$ fue mayor en las hojas de G3-Kt que en las de G1-Kt, pero mayores en G1-Ost que en G3-Ost. Las concentraciones foliares de Mn y Cu con G3-Kt superaron significativamente a los determinados en G1-Kt. Conclusión. La altura, el área de un corte transversal del tronco, así como el volumen y el diámetro de copa fueron mayores con Gomera 3, reflejando la vigorosidad de este portainjerto. Las combinaciones G1-Ost y G3-Kt registraron los máximos rendimientos de frutos, sugiriendo posibilidades prometedoras para incrementar las producciones subtropicales de mango.

España / Mangifera indica / ensayos de variedades / portainjertos / rendimiento / nutrición de las plantas 